\title{
A Sociological Analysis of Cultural Imperialism of International Media on Pakistani Youth
}

\section{Moazzama Naseer}

Department of Sociology, University of Sargodha

Dr. Yasir Nawaz

Department of Sociology, University of Sargodha

Zarqa Azhar

Department of Sociology, University of Sargodha

Zeba Andleeb

Department of Sociology, University of Sargodha

Umair Ahmed

Department of Sociology, University of Sargodha

Dr. Farah Riaz

Department of Home Economics, University of Agriculture, Faisalabad

Doi:10.5901/mjss.2014.v5n3p523

\begin{abstract}
The research was conducted an analysis of cultural imperialism because if the national media of any country absorbs the change from the international channels then the viewers are ready to adopt those changes. Different channels are driving away our cultural boundaries, shaping the perceptions and dreams of ordinary citizens, affecting our language, influencing traditional values and ways of thinking for a long time. In every society it is the natural phenomenon that the true representative of its culture is said to be always the educated class and youth which firstly brings any change and then pervades it in to the society. The objectives of the study were to examine the people perception about International media that to what extent they are changing our cultural patterns and to find out the respondents' views about media influence on our identity. For this purpose descriptive approach was used. Population of the study consists of 150 students of University of Sargodha and Bahauddin Zakariya University. The questionnaire was used as research tool and had sixty five close ended questions. The results indicate that International media strongly influence youngsters in negative direction. It is found that these channels has vital role in replacing Pakistani culture with other cultures and changing life style, language and other aspects of Pakistani people. The results of the study showed that youngsters frequently watched international channels and frequent exposure to these channels plays a significant role in shaping their life style and identity. It was concluded that television channels with positive social values should be emphasized while the negative social values should be de-emphasized. It has been noted that in most of the programs that youngsters watch negative values are mostly portrayed while the positive values are at the background. At International media they watch use of alcohol, cigarettes and love affairs etc in their serials which negatively influence their lifestyle and identity.
\end{abstract}

\section{Introduction}

Pakistan is one of those developing countries which are suffering from cultural imperialism due to the International media. In order to understand the concept of "Cultural imperialism", it must be clear what is meant by "Culture". Imperialism can be defined as "the policy extending a nation's authority by territorial gain, or by the establishment of cultural and economic dominance over other nations".

Cultural Imperialism occurs when one culture dominate another country's culture. Media has a direct impact on 
cultures by mesmerizing viewers with entertainment cultural products, fast music, popularizing different fashions, lifestyles, language and cultures. Media channels are assumed to erase difference among human societies and create a universal culture in which particular characteristics of national and local cultures are no longer relevant. Media is seen as a modern form of imperialism and destroying individual cultures \& diversity.

Every society has its own a particular culture and a culture is an identity of any individual and nation. Pakistani culture is based on Islam and Islam is the religion which is professed and practiced by the people of Pakistan.

Every society has its own a particular culture and a culture is an identity of any individual and nation. The Muslims were highly affected by the Hindu's culture because of living with them together for a longer period in Sub-Continent. In this way, now we are facing cultural conflict and identity crisis at a large scale (Murtaza, 2007).

Every society has diverse civilization (Lane and Ersson, 2007). Culture rules almost every aspect of our life such as music, literature, visual arts, architecture or language and life style. Actually, the things shaped by a culture which we recognize with our five senses are simply demonstrate the deeper meaning of culture- what we do, think and feel. Culture is taught, learned and shared with every member of society (CIL, 2005). There are two types of culture. First is material culture and second non-material. Material culture includes tangible things that have been shaped to some extent by man such things often called "artifacts" or culture objects for instance outfits, domestic substances, armaments etc. Non material culture on the other hand, includes intangible features of culture such as religious beliefs, values, views, morals etc (Dash, 2004).

Islam in Pakistan sets the code of ethics for the cultural life for the people of Pakistan but People adapt western and Indian culture due to acculturation, modernization and westernization (Batool, 2007). The effects of Indian culture are fairly visible on our marriage ceremonies and festivals. Dowry system and heavy expenses on the marriage of girls are done which are inherited from Hindu society because in Hindu society there is no share of women in the inheritance of their parents the same attribute of parents in giving this share to their daughters after their marriage is visible in Pakistan, reflecting the adaptation of Indian cultural values to this Pakistani culture.

Whenever mobile phones in Pakistan ring, 70 million people's ring-tone is usually the title song of several Indian movies. One side effect of this interaction is that national language of Pakistan; Urdu can be once again merged partially with Hindi (Flangan, 2005). Basant is not the part of Pakistani culture and we have to face a great loss of people and finance due to tragic phenomenon of kite flying (Mehmood, 2007; Afzal, 2010).

Television as an electronic medium has transformed the mass media and its main traditional functions of information, education and entertainment. The medium has been of remarkable effect whether positive or negative as it has changed the way we socialize with our friends and teachers method of teaching. It has changed the way we organize the furniture in our homes and our world view about our immediate environment (Baran, 2009). A social critic, Novak, cited in Vivian (2009), notes that television is "a determinant of the soul's geography. It builds up incrementally a cognitive arrangement of expectations. It does so in much the same way that school lessons slowly, over the years, tutor the unformed mind and teach it how to think." Various families no longer watch television together and parents often do not know what their children especially teenagers are viewing. Unsupervised freedom has almost always been considered a major source of trouble and threat to young people's moral development (Muncie, 2004).

There is no doubt that the impact of the media on young people's lives is broadly considered within what is referred to as "media effects" debate which to a great extent focuses on the potentially negative impact of the media on young people's lives: video violence, gambling, educational performance, mass consumerism etc (Miles, 2000). Unfortunately, because most youngsters are still looking for their own identities, they are a lot more capable to suggestion and all the perceived peer stress from the media can overcome what they have already formed of their own identities based on someone else's opinions, what they should think and feel. Without realizing it they can start picking up someone else's opinions instead of forming their own with the way the media is today (George-Okoro, 2008). There is no denying fact that television operators can play a vital role in the development of national character and identity. Monetary benefits aside, cable operators have involved themselves in promoting and spoiling of our social values and customs (Nisar, 2002).

\subsection{Objectives of the study:}

The proposed research study intends to achieve following objectives.

1. To explore the socioeconomic and demographic characteristics of respondents

2. To examine the people perception about International channels to what extent they are changing our cultural patterns. 
3. To find out the respondents' views about media influence on our identity.

\subsection{Conceptual framework}

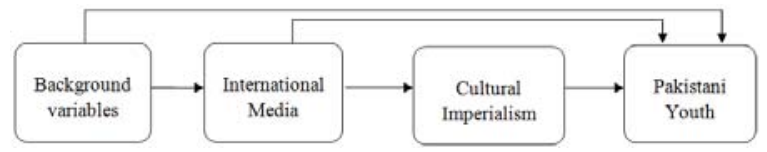

\section{Methodology of Study}

In this study the researcher want to find out the effects of International media on Pakistani youth.In order to make this study systematic certain procedures and steps were designed starting from the selection of population and sample to the data analysis. In order to ensure an effective study researcher used Quantitative research design. Data was collected from students of Bahauddin Zakariya University and university of Sargodha. The major reason for selecting young and educated population was that they are more frequent to bring about changes into their behavior and life styles due to media influence. Therefore, the population for this study were all youngsters between the ages 18-26 years in Bahauddin Zakariya University and University of Sargodha. Multistage sampling technique were used for the selecting of the respondent for the study, in the first stage, simple random sampling technique was used to select two universities (Bahauddin Zakariya University and University of Sargodha) from Government Universities of Punjab. In second stage, fiveDepartments were selected randomly from the both selected Universities. Due to limited resources and time researcher has selected sample size of 150 students. The researcher divided the sample size by the 10 Departments to get about 15 respondents per selected Department by using convenient sampling technique. The instruments used for collecting data in this study was Self-developed questionnaire forsurveyand this tool seemed more appropriate because it was easy to respond. The study employed descriptive statistics to summarize and describe the data whereas inferential statistics such as Chi-square and Gamma test were used to examine the relationship between predictors and response variables.

\section{Results and Discussion}

Table 1: Socio-demographic information of respondents:

\begin{tabular}{|c|c|c|}
\hline Gender & Frequency & Percentage \\
\hline Male & 69 & 46.0 \\
\hline Female & 81 & 54.0 \\
\hline Mean $^{\star} \quad=1.54$ & & \\
\hline \multicolumn{3}{|l|}{ Age (Years) } \\
\hline $18-20$ & 14 & 9.3 \\
\hline $21-23$ & 85 & 56.7 \\
\hline $24-26$ & 51 & 34.0 \\
\hline S.D. $=.612$ & & \\
\hline \multicolumn{3}{|l|}{ Education level } \\
\hline Intermediate & 3 & 2.0 \\
\hline Graduate & 36 & 24.0 \\
\hline Masters & 103 & 68.7 \\
\hline M. Phil & 8 & 5.3 \\
\hline Mean $^{*}=2.77$ & & \\
\hline \multicolumn{3}{|l|}{ Family type } \\
\hline Nuclear & 69 & 46.0 \\
\hline Joint & 76 & 50.7 \\
\hline Extended & 5 & 3.3 \\
\hline \multicolumn{3}{|l|}{ Father's education } \\
\hline Illiterate & 15 & 10.0 \\
\hline Matriculation & 41 & 27.3 \\
\hline Intermediate & 31 & 20.7 \\
\hline
\end{tabular}




\begin{tabular}{|l|c|c|}
\hline Graduation & 32 & 21.3 \\
\hline Masters - above & 31 & 20.7 \\
\hline Family monthly income & \multicolumn{2}{|c|}{} \\
\hline $20,000-30,000$ & 17 & 11.3 \\
\hline $31,000-40,000$ & 11 & 7.3 \\
\hline $41,000-50,000$ & 40 & 26.7 \\
\hline $51,000-60,000$ & 38 & 25.3 \\
\hline Above 60,000 & 44 & 29.3 \\
\hline Mean ${ }^{*}=3.54 \quad$ S.D. $=1.293$ & & 100 \\
\hline Total & 150 & \\
\hline
\end{tabular}

Table 1 indicates that a majority of respondents $56.7 \%$ were $21-23$ years and $34.0 \%$ respondents were $24-26$ years while $9.3 \%$ of the respondents were $18-20$ years old.

Table, showed the distribution of respondents regarding their age $54.0 \%$ of respondents were females while $46.0 \%$ were male respondents.

Table, represents the distribution of respondents regarding their qualification 2.0 percent of the respondents were intermediate, 24.0 were graduates and 68.7 percent of them were masters and 5.3 percent of them were M. Phil students.

Table shows that $11.3 \%$ respondents had income 20 to 30 thousands, $7.3 \%$ had income from 31 to 40 thousands, $26.7 \%$ fell in category of 41 to 50 thousands, $25.3 \%$ had income from 51 thousands to 60 while $29.3 \%$ of respondents had above 60 thousand income.

\subsection{Descriptive analysis}

The table contains descriptive statistics of first independent variable in this study. Five columns of table describe frequencies and percentages of responses given by respondents. Final two columns describe mean and standard deviation. The data presented in table illustrate that mostly respondents are agreed upon the influence of foreign channels on youngsters.

Table 2: Electronic Media

\begin{tabular}{|c|c|c|c|c|c|c|c|c|c|c|c|c|}
\hline Electronic Media & & $\begin{array}{l}\text { ngly } \\
\text { ree }\end{array}$ & & gree & Neitl & $\begin{array}{l}\text { gree Nor } \\
\text { ree }\end{array}$ & Dis & agree & & $\begin{array}{l}\text { ngly } \\
\text { gree }\end{array}$ & & \\
\hline Statements & $\mathrm{F}$. & $\%$ & $\mathrm{~F}$. & $\%$ & $\mathrm{~F}$. & $\%$ & $\mathrm{~F}$. & $\%$ & $\mathrm{~F}$. & $\%$ & Mean & S.D. \\
\hline $\begin{array}{l}\text { I prefer to watch Indian channels than } \\
\text { Pakistani channels }\end{array}$ & 32 & 21.3 & 49 & 32.7 & 19 & 12.7 & 35 & 23.3 & 15 & 10.0 & 2.68 & 1.312 \\
\hline $\begin{array}{l}\text { Indian programs are better than Pakistani } \\
\text { programs in Script }\end{array}$ & 25 & 16.7 & 42 & 28.0 & 31 & 20.7 & 33 & 22.0 & 19 & 12.7 & 2.86 & 1.290 \\
\hline $\begin{array}{l}\text { Media is responsible for changing value } \\
\text { system of society }\end{array}$ & 56 & 37.3 & 64 & 42.7 & 9 & 6.0 & 15 & 10.0 & 6 & 4.0 & 2.01 & 1.096 \\
\hline $\begin{array}{l}\text { Media is promoting western culture in the } \\
\text { name of modernization }\end{array}$ & 53 & 35.3 & 63 & 42.0 & 17 & 11.3 & 11 & 7.3 & 6 & 4.0 & 2.03 & 1.062 \\
\hline $\begin{array}{l}\text { Watching tv keeps me informed what is } \\
\text { happening around the world }\end{array}$ & 58 & 38.7 & 56 & 37.3 & 24 & 16.0 & 8 & 5.3 & 4 & 2.7 & 1.96 & 1.003 \\
\hline I like to watch Foreign channels & 31 & 20.7 & 57 & 38.0 & 33 & 22.0 & 24 & 16.0 & 5 & 3.3 & 2.43 & 1.089 \\
\hline I watch Indian programs regularly & 28 & 18.7 & 39 & 26.0 & 23 & 15.3 & 43 & 28.7 & 17 & 11.3 & 2.88 & 1.321 \\
\hline
\end{tabular}

Table 2 illustrates the responses of respondents on the influence of foreign channels on youngsters. The response of $1^{\text {st }}$ statement "I prefer to watch Indian channels than Pakistani channels" is positive as 32.7\% showed agreed response and $23.3 \%$ of respondents showed disagreed response while $12.7 \%$ wee neutral, $21.3 \%$ were strongly agree $10.0 \%$ were strongly disagree .

The $2^{\text {nd }}$ statement "Indian programs are better than Pakistani programs in Script" shows that $28.0 \%$ respondents were agreed and $22.0 \%$ were disagreed to this statement while $20.7 \%$ were neutral, $16.7 \%$ were strongly agree and $12.7 \%$ were strongly disagree.

The $3^{\text {rd }}$ statement of this table "Media is responsible for changing value system of society" reveals that $42.7 \%$ of 
respondents were agree and $10.0 \%$ respondents were disagree while $6.0 \%$ were neutral, 37.3 were strongly agree and $4.0 \%$ were strongly disagree. So, majority of respondents has believed that media is changing the value system of Pakistani society.

The $4^{\text {th }}$ statements "Media is promoting western culture in the name of modernization" indicates that majority of respondents $42.0 \%$ were agree and $7.3 \%$ were disagree while $35.3 \%$ were strongly agree, $2.03 \%$ responds were strongly disagree and $11.3 \%$ were neutral.

The $5^{\text {th }}$ statement of this table "Watching tv keeps me informed what is happening around the world" shows that 38.7 respondents were strongly agree while $2.7 \%$ were strongly disagree with this statement while $37.3 \%$ were agree, $5.3 \%$ were disagree and $16.0 \%$ respondents were neutral.

The $6^{\text {th }}$ statement "I like to watch foreign channels" reveals that $38.0 \%$ respondents were agree and $16.0 \%$ were disagree while $20.7 \%$ were strongly agree, $3.3 \%$ were strongly disagree and $22.0 \%$ respondents were neither agree nor disagree.

The $7^{\text {th }}$ statement of this table "I watch Indian programs regularly" indicates that $28.7 \%$ respondents were disagree and $26.0 \%$ were agree with this statement while $18.7 \%$ were strongly agree, $11.3 \%$ were strongly disagree and $15.3 \%$ were neutral.

Table 3: Cultural Patterns

\begin{tabular}{|c|c|c|c|c|c|c|c|c|c|c|c|c|}
\hline Cultural Patterns & \multicolumn{2}{|c|}{$\begin{array}{l}\text { Strongly } \\
\text { Agree }\end{array}$} & \multicolumn{2}{|c|}{ Agree } & \multicolumn{2}{|c|}{$\begin{array}{l}\text { Neither Agree Nor } \\
\text { Disagree }\end{array}$} & \multicolumn{2}{|c|}{ Disagree } & \multicolumn{2}{|c|}{$\begin{array}{l}\text { Strongly } \\
\text { Disagree }\end{array}$} & \multirow[b]{2}{*}{ Mean } & \multirow[b]{2}{*}{ S.D. } \\
\hline Statements & F. & $\%$ & $\mathrm{~F}$. & $\%$ & $\mathrm{~F}$. & $\%$ & $\mathrm{~F}$. & $\%$ & F. & $\%$ & & \\
\hline $\begin{array}{l}\text { Pakistani media is playing a vital role to } \\
\text { promote Indian culture }\end{array}$ & 39 & 26.0 & 84 & 56.0 & 8 & 5.3 & 8 & 5.3 & 11 & 7.3 & 2.12 & 1.086 \\
\hline $\begin{array}{l}\text { I learn how to interact with others from } \\
\text { media rather than other social institutions }\end{array}$ & 36 & 24.0 & 71 & 47.3 & 16 & 10.7 & 18 & 12.0 & 9 & 6.0 & 2.29 & 1.137 \\
\hline $\begin{array}{l}\text { Regular exposure to media helps me to } \\
\text { develop views concerning social behavior }\end{array}$ & 32 & 21.3 & 80 & 53.3 & 15 & 10.0 & 11 & 7.3 & 12 & 8.0 & 2.27 & 1.123 \\
\hline $\begin{array}{l}\text { We are performing Indian traditions and } \\
\text { customs in our ceremonies }\end{array}$ & 40 & 26.7 & 58 & 38.7 & 23 & 15.3 & 15 & 10.0 & 14 & 9.3 & 2.37 & 1.239 \\
\hline $\begin{array}{l}\text { Media is spoiling the real picture of Pakistani } \\
\text { culture }\end{array}$ & 34 & 22.7 & 73 & 48.7 & 18 & 12.0 & 15 & 10.0 & 10 & 6.7 & 2.29 & 1.127 \\
\hline $\begin{array}{l}\text { Indian programs are affecting my social } \\
\text { values }\end{array}$ & 48 & 32.0 & 47 & 31.3 & 24 & 16.0 & 22 & 14.7 & 9 & 6.0 & 2.31 & 1.232 \\
\hline $\begin{array}{l}\text { Youth is the most affected generation to } \\
\text { adopt cultural changes }\end{array}$ & 61 & 40.7 & 52 & 34.7 & 15 & 10.0 & 10 & 6.7 & 12 & 8.0 & 2.07 & 1.224 \\
\hline
\end{tabular}

Table 3 depicts the responses of respondents on the influence of foreign media on our cultural patterns. The response of $1^{\text {st }}$ statement "Pakistani media is playing a vital role to promote Indian Culture" is showed $56.0 \%$ agreed response while $5.3 \%$ of respondents showed disagreed response while $26.0 \%$ were strongly agree, $7.3 \%$ were strongly disagree while $5.3 \%$ respondents were neutral with this statement.

The $2^{\text {nd }}$ statement "I learn how to interact with others from media rather than other social institutions" shows that $47.3 \%$ respondents were agreed and $12.0 \%$ were disagreed to this statement while $10.7 \%$ were neutral, $24.0 \%$ were strongly agree and $6.0 \%$ were strongly disagree.

The $3^{\text {rd }}$ statement of this table "Regular exposure to media helps me to develop views concerning social behavior" reveals that $53.3 \%$ of respondents were agree and $7.3 \%$ respondents were disagree while $10.0 \%$ were neutral, $21.3 \%$ were strongly agree and $8.0 \%$ were strongly disagree with this statement.

The $4^{\text {th }}$ statements "We are performing Indian traditions and customs in our ceremonies" indicates that majority of respondents $38.7 \%$ were agree and $10.0 \%$ were disagree while $26.7 \%$ were strongly agree, $9.3 \%$ responds were strongly disagree while $15.3 \%$ were neutral.

The $5^{\text {th }}$ statement of this table "Media is spoiling the real picture of Pakistani culture" shows that $48.7 \%$ respondents were agree while $10.0 \%$ were disagree with this statement while $22.7 \%$ were strongly agree, $6.7 \%$ were strongly disagree and $12.0 \%$ respondents were neutral.

The $6^{\text {th }}$ statement "Indian programs are affecting my social values" reveals that $32.0 \%$ respondents were strongly agree and $6.0 \%$ were strongly disagree while $31.3 \%$ were agree, $14.7 \%$ were disagree and $16.0 \%$ respondents were neither agree nor disagree. 
The $7^{\text {th }}$ statement of this table "Youth is the most affected generation to adopt cultural changes" indicates that $40.7 \%$ respondents were strongly agree and $8.0 \%$ were strongly disagree with this statement while $34.7 \%$ were agree, $6.7 \%$ were disagree and $10.0 \%$ were neutral.

Table 4: Life Style

\begin{tabular}{|l|c|c|c|c|c|c|c|c|c|c|c|c|}
\hline \multicolumn{1}{|c|}{ Life Style } & \multicolumn{2}{|c|}{$\begin{array}{c}\text { Strongly } \\
\text { Agree }\end{array}$} & \multicolumn{2}{|c|}{ Agree } & \multicolumn{2}{c|}{$\begin{array}{c}\text { Neither Agree Nor } \\
\text { Disagree }\end{array}$} & \multicolumn{2}{c|}{ Disagree } & \multicolumn{2}{c|}{$\begin{array}{l}\text { Strongly } \\
\text { Disagree }\end{array}$} & & \\
\hline \multicolumn{1}{|c|}{ Statements } & F. & $\%$ & F. & $\%$ & F. & $\%$ & F. & $\%$ & F. & $\%$ & Mean & S.D. \\
\hline $\begin{array}{l}\text { I desire to adopt the way of life portrayed in the } \\
\text { tv programs }\end{array}$ & 30 & 20.0 & 71 & 47.3 & 15 & 10.0 & 19 & 12.7 & 15 & 10.0 & 2.45 & 1.229 \\
\hline $\begin{array}{l}\text { I have an impact of Indian style on my living } \\
\text { manner }\end{array}$ & 28 & 18.7 & 50 & 33.3 & 27 & 18.0 & 28 & 18.7 & 17 & 11.3 & 2.71 & 1.283 \\
\hline $\begin{array}{l}\text { I watch tv channels due to celebrities and their } \\
\text { lifestyle shown in different programs }\end{array}$ & 26 & 17.3 & 65 & 43.3 & 21 & 14.0 & 24 & 16.0 & 14 & 9.3 & 2.57 & 1.217 \\
\hline $\begin{array}{l}\text { The ideal and acceptable dressing style is as } \\
\text { portrayed in the tv channels }\end{array}$ & 30 & 20.0 & 56 & 37.3 & 27 & 18.0 & 28 & 18.7 & 9 & 6.0 & 2.53 & 1.180 \\
\hline $\begin{array}{l}\text { Concept of veil in females is declining due to } \\
\text { the influence of Indian/western culture }\end{array}$ & 44 & 29.3 & 73 & 48.7 & 14 & 9.3 & 13 & 8.7 & 6 & 4.0 & 2.09 & 1.045 \\
\hline Tv programs made an impact on my daily life & 31 & 20.7 & 72 & 48.0 & 17 & 11.3 & 15 & 10.0 & 15 & 10.0 & 2.41 & 1.210 \\
\hline $\begin{array}{l}\text { Indian/western culture is affecting the life style } \\
\text { of Pakistani people }\end{array}$ & 50 & 33.3 & 64 & 42.7 & 12 & 8.0 & 13 & 8.7 & 11 & 7.3 & 2.14 & 1.187 \\
\hline
\end{tabular}

Table 4 represents the responses of respondents about the effect of media on our lifestyle. The response of 1 st statement "I desire to adopt the way of life portrayed in the tv programs" is showed $47.3 \%$ agreed response and $12.7 \%$ of respondents showed disagree response while $20.0 \%$ were strongly agree, $10.0 \%$ were strongly disagree while $10.0 \%$ respondents were neutral with this statement.

The $2^{\text {nd }}$ statement "I have an impact of Indian style on my living manner" shows that $33.3 \%$ respondents were agreed and $18.7 \%$ were disagreed to this statement while $18.0 \%$ were neutral, $18.7 \%$ were strongly agree and $11.3 \%$ were strongly disagree.

The $3^{\text {rd }}$ statement of this table "I watch tv channels due to celebrities and their lifestyle shown in different programs" reveals that $43.3 \%$ of respondents were agree and $16.0 \%$ respondents were disagree while $14.0 \%$ were neutral, $17.3 \%$ were strongly agree and $9.3 \%$ were strongly disagree with this statement.

The $4^{\text {th }}$ statements "The ideal and acceptable dressing style is as portrayed in the tv channels" indicates that majority of respondents $37.3 \%$ were agree and $18.7 \%$ were disagree while $20.0 \%$ were strongly agree, $6.0 \%$ responds were strongly disagree while $18.0 \%$ were neutral.

The $5^{\text {th }}$ statement of this table "Concept of veil in females is declining due to the influence of Indian/western culture" shows that $48.7 \%$ respondents were agree while $8.7 \%$ were disagree with this statement while $29.3 \%$ were strongly agree, $4.0 \%$ were strongly disagree and $9.3 \%$ respondents were neutral.

The $6^{\text {th }}$ statement "Tv programs made an impact on my daily life" reveals that $42.7 \%$ respondents were agree and $10.0 \%$ were disagree while $20.7 \%$ were strongly agree, $7.3 \%$ were strongly disagree and $11.3 \%$ respondents were neither agree nor disagree.

The $7^{\text {th }}$ statement of this table "Indian/western culture is affecting the life style of Pakistani people" indicates that $42.7 \%$ respondents were agree and $8.7 \%$ were disagree with this statement while $33.3 \%$ were strongly agree, $7.3 \%$ were strongly disagree and $8.0 \%$ were neutral.

\section{Table 5: Violence}

\begin{tabular}{|l|c|c|c|c|c|c|c|c|c|c|c|c|}
\hline \multicolumn{1}{|c|}{ Violence } & \multicolumn{2}{c|}{$\begin{array}{c}\text { Strongly } \\
\text { Agree }\end{array}$} & \multicolumn{2}{c|}{ Agree } & \multicolumn{2}{c|}{$\begin{array}{c}\text { Neither Agree Nor } \\
\text { Disagree }\end{array}$} & Disagree & \multicolumn{2}{c|}{$\begin{array}{c}\text { Strongly } \\
\text { Disagree }\end{array}$} & & \\
\hline \multicolumn{1}{|c|}{ Statements } & F. & $\%$ & F & $\%$ & F. & $\%$ & F. & $\%$ & F. & $\%$ & Mean & S.D. \\
\hline $\begin{array}{l}\text { Programs on TV channels have negative impact } \\
\text { on youngster's social behavior }\end{array}$ & 47 & 31.3 & 81 & 54.0 & 5 & 3.3 & 8 & 5.3 & 8 & 5.3 & 2.05 & 1.260 \\
\hline $\begin{array}{l}\text { Tv channels have influenced the youngsters to } \\
\text { participate in crimes }\end{array}$ & 32 & 21.3 & 81 & 54.0 & 22 & 14.7 & 11 & 7.3 & 4 & 2.7 & 2.16 & .935 \\
\hline
\end{tabular}




\begin{tabular}{|l|c|c|c|c|c|c|c|c|c|c|c|c|}
\hline $\begin{array}{l}\text { The ratio of kidnapping and murders has } \\
\text { increased due to violence shown in movies }\end{array}$ & 47 & 31.3 & 78 & 52.0 & 14 & 9.3 & 10 & 6.7 & 1 & .7 & 1.93 & .857 \\
\hline $\begin{array}{l}\text { Youngsters are abundantly doing smoking due to } \\
\text { impact of Indian and western channels }\end{array}$ & 46 & 30.7 & 68 & 45.3 & 23 & 15.3 & 11 & 7.3 & 2 & 1.3 & 2.03 & .937 \\
\hline $\begin{array}{l}\text { Indian channels/movies are increasing violent } \\
\text { behavior among youngsters }\end{array}$ & 40 & 26.7 & 76 & 50.7 & 22 & 14.7 & 7 & 4.7 & 5 & 3.3 & 2.07 & .949 \\
\hline $\begin{array}{l}\text { Indian/western programs have brought a } \\
\text { negative change in our } \\
\text { Society }\end{array}$ & 40 & 26.7 & 74 & 49.3 & 18 & 12.0 & 10 & 6.7 & 8 & 5.3 & 2.15 & 1.058 \\
\hline $\begin{array}{l}\text { Violent or offensive acts are portrayed on tv } \\
\text { channels }\end{array}$ & 52 & 34.7 & 69 & 46.0 & 11 & 7.3 & 3 & 2.0 & 15 & 10.0 & 2.07 & 1.185 \\
\hline
\end{tabular}

Table 5 illustrates the responses of respondents about the effect of media on the ratio of violence among Pakistani youth. The response of $1^{\text {st }}$ statement "Programs on TV channels have negative impact on youngster's social behavior" is showed $54.0 \%$ agreed response and $5.3 \%$ of respondents showed disagree response while $31.3 \%$ were strongly agree, $15.3 \%$ were strongly disagree while $3.3 \%$ respondents were neutral with this statement.

The $2^{\text {nd }}$ statement "Tv channels have influenced the youngsters to participate in crimes" shows that $54.0 \%$ respondents were agreed and $7.3 \%$ were disagreed to this statement while $14.7 \%$ were neutral, $21.3 \%$ were strongly agree and $2.7 \%$ were strongly disagree.

The $3^{\text {rd }}$ statement of this table "The ratio of kidnapping and murders has increased due to violence shown in movies" reveals that $52.0 \%$ of respondents were agree and $6.7 \%$ respondents were disagree while $9.3 \%$ were neutral, $31.3 \%$ were strongly agree and .7\% were strongly disagree with this statement.

The $4^{\text {th }}$ statements "Youngsters are abundantly doing smoking due to impact of Indian and western channels" indicates that majority of respondents $45.3 \%$ were agree and $7.3 \%$ were disagree while $30.7 \%$ were strongly agree, $1.3 \%$ responds were strongly disagree while $15.3 \%$ were neutral.

The $5^{\text {th }}$ statement of this table "Indian channels/movies are increasing violent behavior among youngsters" shows that $50.7 \%$ respondents were agree while $4.7 \%$ were disagree with this statement while $26.7 \%$ were strongly agree, $3.3 \%$ were strongly disagree and $14.7 \%$ respondents were neutral.

The $6^{\text {th }}$ statement "Indian/western programs have brought a negative change in our Society" reveals that $49.3 \%$ respondents were agree and $6.7 \%$ were disagree while $26.7 \%$ were strongly agree, $5.3 \%$ were strongly disagree and $12.0 \%$ respondents were neither agree nor disagree.

The $7^{\text {th }}$ statement of this table "Violent or offensive acts are portrayed on tv channels" indicates that $46.0 \%$ respondents were agree and $2.0 \%$ were disagree with this statement while $34.7 \%$ were strongly agree, $10.0 \%$ were strongly disagree and $7.3 \%$ were neutral.

Table 6: Language

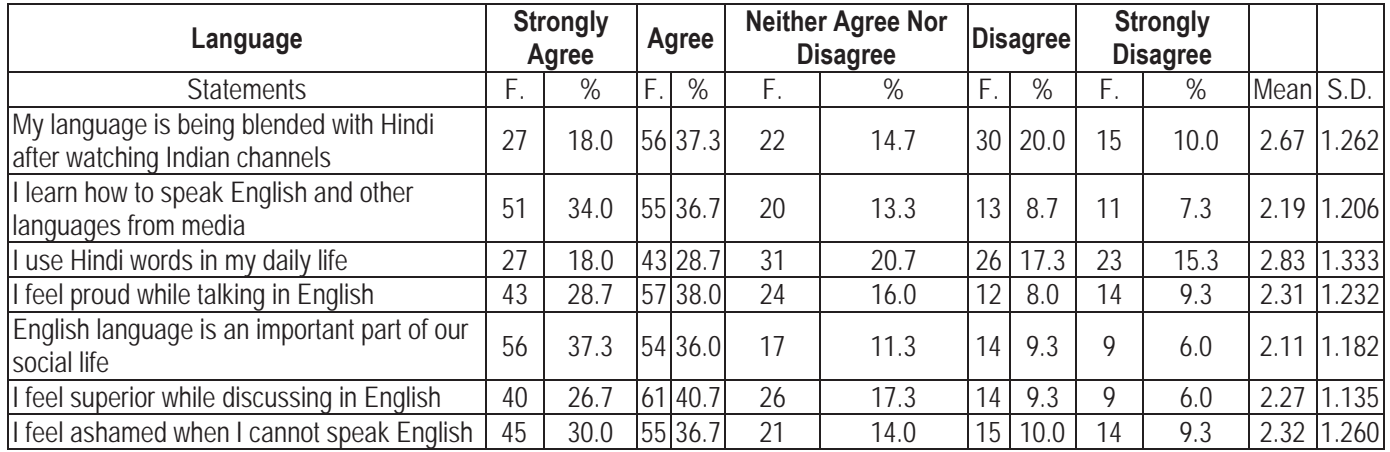

Table 6 demonstrates the responses of respondents about the effect of media on our language. The response of $1^{\text {st }}$ statement "My language is being blended with Hindi after watching Indian channels" is showed $37.3 \%$ agreed response and $20.0 \%$ of respondents showed disagree response while $18.0 \%$ were strongly agree, $10.0 \%$ were strongly disagree while $14.7 \%$ respondents were neutral with this statement. 
The $2^{\text {nd }}$ statement "I learn how to speak English and other languages from media" shows that $36.7 \%$ respondents were agreed and $8.7 \%$ were disagreed to this statement while $13.3 \%$ were neutral, $34.0 \%$ were strongly agree and $7.3 \%$ were strongly disagree.

The $3^{\text {rd }}$ statement of this table "I use Hindi words in my daily life" reveals that $28.7 \%$ of respondents were agree and $17.3 \%$ respondents were disagree while $20.7 \%$ were neutral, $18.0 \%$ were strongly agree and $15.3 \%$ were strongly disagree with this statement.

The $4^{\text {th }}$ statements "I feel proud while talking in English" indicates that majority of respondents $38.0 \%$ were agree and $8.0 \%$ were disagree while $28.7 \%$ were strongly agree, $9.3 \%$ responds were strongly disagree while $16.0 \%$ were neutral.

The $5^{\text {th }}$ statement of this table "English language is an important part of our social life" shows that $37.3 \%$ respondents were strongly agree while $6.0 \%$ were strongly disagree with this statement while $36.0 \%$ were agree, $9.3 \%$ were disagree and $11.3 \%$ respondents were neutral.

The $6^{\text {th }}$ statement "I feel superior while discussing in English" reveals that $40.7 \%$ respondents were agree and $9.3 \%$ were disagree while $26.7 \%$ were strongly agree, $6.0 \%$ were strongly disagree and $17.3 \%$ respondents were neither agree nor disagree.

The $7^{\text {th }}$ statement of this table "I feel ashamed when I cannot speak English" indicates that $36.7 \%$ respondents were agree and $10.0 \%$ were disagree with this statement while $30.0 \%$ were strongly agree, $9.3 \%$ were strongly disagree and $14.0 \%$ were neutral.

Table 7: Identity

\begin{tabular}{|c|c|c|c|c|c|c|c|c|c|c|c|c|}
\hline Identity & \multicolumn{2}{|c|}{$\begin{array}{l}\text { Strongly } \\
\text { Agree }\end{array}$} & \multicolumn{2}{|c|}{ Agree } & \multicolumn{2}{|c|}{$\begin{array}{l}\text { Neither Agree Nor } \\
\text { Disagree }\end{array}$} & \multicolumn{2}{|c|}{ Disagree } & \multicolumn{2}{|c|}{$\begin{array}{l}\text { Strongly } \\
\text { Disagree }\end{array}$} & \multirow[b]{2}{*}{ Mean } & \multirow[b]{2}{*}{ S.D. } \\
\hline Statements & F. & $\%$ & $\mathrm{~F}$. & $\%$ & $\mathrm{~F}$. & $\%$ & F. & $\%$ & $\mathrm{~F}$. & $\%$ & & \\
\hline $\begin{array}{l}\text { I like to change myself according to new } \\
\text { trends shown in tv channels }\end{array}$ & 21 & 14.0 & 81 & 54.0 & 14 & 9.3 & 18 & 12.0 & 16 & 10.7 & 2.51 & 1.191 \\
\hline $\begin{array}{l}\text { l like Chinese and fast food than traditional } \\
\text { foods }\end{array}$ & 41 & 27.3 & 53 & 35.3 & 19 & 12.7 & 17 & 11.3 & 20 & 13.3 & 2.48 & 1.355 \\
\hline I have an impact of Indian style of dressing & 22 & 14.7 & 55 & 36.7 & 21 & 14.0 & 34 & 22.7 & 18 & 12.0 & 2.81 & 1.278 \\
\hline I actively participate in basant & 30 & 20.0 & 47 & 31.3 & 32 & 21.3 & 24 & 16.0 & 17 & 11.3 & 2.67 & 1.277 \\
\hline $\begin{array}{l}\text { I like to introduce myself as a modern } \\
\text { person rather than as a traditional }\end{array}$ & 32 & 21.3 & 55 & 36.7 & 27 & 18.0 & 24 & 16.0 & 12 & 8.0 & 2.53 & 1.219 \\
\hline Preference of foreign clothes has increased & 45 & 30.0 & 66 & 44.0 & 21 & 14.0 & 11 & 7.3 & 7 & 4.7 & 2.13 & 1.070 \\
\hline I like to celebrate birthday parties & 43 & 28.7 & 68 & 45.3 & 16 & 10.7 & 13 & 8.7 & 10 & 6.7 & 2.19 & 1.145 \\
\hline $\begin{array}{l}\text { Identity Crisis is clearly visible in the actions } \\
\text { of Pakistani youth }\end{array}$ & 49 & 32.7 & 61 & 40.7 & 22 & 14.7 & 12 & 8.0 & 6 & 4.0 & 2.10 & 1.073 \\
\hline
\end{tabular}

Table 7 represents the responses of respondents about the effect of foreign media on our Identity. The response of $1^{\text {st }}$ statement "I like to change myself according to new trends shown in tv channels" is showed $54.0 \%$ agreed response and $12.0 \%$ of respondents showed disagree response while $14.0 \%$ were strongly agree, $10.7 \%$ were strongly disagree while $9.3 \%$ respondents were neutral with this statement.

The $2^{\text {nd }}$ statement "I like Chinese and fast food than traditional foods" shows that $35.3 \%$ respondents were agreed and $11.3 \%$ were disagreed to this statement while $12.7 \%$ were neutral, $27.3 \%$ were strongly agree and $13.3 \%$ were strongly disagree.

The $3^{\text {rd }}$ statement of this table "I have an impact of Indian style of dressing" reveals that $36.7 \%$ of respondents were agree and $22.7 \%$ respondents were disagree while $14.0 \%$ were neutral, $14.7 \%$ were strongly agree and $12.0 \%$ were strongly disagree with this statement.

The $4^{\text {th }}$ statements "I actively participate in basant" indicates that majority of respondents $31.3 \%$ were agree and $16.0 \%$ were disagree while $20.0 \%$ were strongly agree, $11.3 \%$ responds were strongly disagree while $21.3 \%$ were neutral.

The $5^{\text {th }}$ statement of this table "I like to introduce myself as a modern person rather than as a traditional" shows that $36.7 \%$ respondents were agree and $7.3 \%$ were disagree with this statement while $21.3 \%$ were strongly agree, $8.0 \%$ were strongly disagree and $18.0 \%$ respondents were neutral.

The $6^{\text {th }}$ statement "Preference of foreign clothes has increased" reveals that $44.0 \%$ respondents were agree and 
$7.3 \%$ were disagree while $30.0 \%$ were strongly agree, $4.7 \%$ were strongly disagree and $14.0 \%$ respondents were neither agree nor disagree.

The $7^{\text {th }}$ statement of this table "I like to celebrate birthday parties" indicates that $45.3 \%$ respondents were agree and $8.7 \%$ were disagree with this statement while $28.7 \%$ were strongly agree, $6.7 \%$ were strongly disagree and $10.7 \%$ were neutral.

The $8^{\text {th }}$ statement of last table "Identity Crisis is clearly visible in the actions of Pakistani youth" shows that $40.7 \%$ respondents were agree with this statement and $8.0 \%$ were disagree while $32.7 \%$ were strongly agree, $4.0 \%$ were strongly disagree and $14.7 \%$ respondents were neither agree nor disagree.

\section{(Bi-variate Analysis)}

\section{Testing of Hypothesis}

\subsection{Hypothesis 1: Media plays a significant role in changing life style of youngsters.}

Table 8: Association between attitude towards media and changing life style

\begin{tabular}{|c|c|c|c|c|}
\hline \multirow{2}{*}{ Attitude towards media } & \multicolumn{3}{|c|}{ Changing life style } & \multirow{2}{*}{ Total } \\
\cline { 2 - 5 } & Low & Medium & High & \\
\hline \multirow{2}{*}{ Low } & 13 & 10 & 1 & 24 \\
\cline { 2 - 5 } & $54.2 \%$ & $41.7 \%$ & $4.2 \%$ & $100.0 \%$ \\
\hline \multirow{2}{*}{ Medium } & 4 & 33 & 31 & 68 \\
\cline { 2 - 5 } & $5.9 \%$ & $48.5 \%$ & $45.6 \%$ & $100.0 \%$ \\
\hline \multirow{2}{*}{ High } & 5 & 15 & 38 & 58 \\
\cline { 2 - 5 } & $8.6 \%$ & $25.9 \%$ & $65.5 \%$ & $100.0 \%$ \\
\hline \multirow{2}{*}{ Total } & 22 & 58 & 70 & 150 \\
\cline { 2 - 5 } & $14.7 \%$ & $38.7 \%$ & $46.7 \%$ & $100.0 \%$ \\
\hline
\end{tabular}

Chi-square $=48.50 ;$ d.f. $=4 ;$ P-value $=.000^{\star \star} ;$ Gamma $=.596 ; * *$ Highly significant

Table 8 presents the association between attitude towards media by the respondents and changing in their life style. Chisquare value (48.50) shows a highly significant $(P=.000)$ association between attitude towards media by the respondents and changing in their life style. Gamma value shows a positive relationship between the variables. It means if the respondents had more favourable attitude towards media, then they had more change in their life as compared to low attitude towards media. So the hypothesis "Media plays a significant role in changing life style of youngsters" is accepted.

\subsection{Hypothesis 2: Frequency of exposure to media plays a vital role in changing our cultural patterns.}

Table 9: Association between attitude towards media and changing our cultural pattern

\begin{tabular}{|c|c|c|c|c|}
\hline \multirow{2}{*}{ Time spend with media (hours) } & \multicolumn{3}{|c|}{ Changing in cultural pattern } & \multirow{2}{*}{ Total } \\
\cline { 2 - 5 } & Low & Medium & High & \\
\hline \multirow{2}{*}{$1-2$} & 12 & 31 & 20 & 63 \\
\cline { 2 - 5 } & $19.1 \%$ & $49.2 \%$ & $31.7 \%$ & $100.0 \%$ \\
\hline \multirow{2}{*}{$3-4$} & 5 & 18 & 37 & 60 \\
\cline { 2 - 5 } & $8.3 \%$ & $30.0 \%$ & $61.7 \%$ & $100.0 \%$ \\
\hline \multirow{2}{*}{$5-6$} & 3 & 5 & 19 & 27 \\
\cline { 2 - 5 } & $11.1 \%$ & $18.5 \%$ & $70.4 \%$ & $100.0 \%$ \\
\hline \multirow{2}{*}{ Total } & 20 & 54 & 76 & 150 \\
\cline { 2 - 5 } & $13.3 \%$ & $36.0 \%$ & $50.7 \%$ & $100.0 \%$ \\
\hline
\end{tabular}

Chi-square $=27.94 ;$ d.f. $=4 ;$ P-value $=.000^{\star *} ;$ Gamma $=.384 ; * *$ Highly significant

Table 9 presents the association between times spend with media by the respondents and changing in their cultural pattern. Chi-square value (27.94) shows a highly significant $(\mathrm{P}=.000)$ association between time spend with media by the respondents and changing in their cultural pattern. Gamma value shows a positive relationship between the variables. It means if the respondents were spending more time with media then they had more changes in their cultural pattern. So the hypothesis "Frequency of exposure to media plays a vital role in changing our cultural patterns" is accepted. 


\subsection{Hypothesis 3: Media of foreign countries strongly cause the identity crises among Pakistani youth.}

Table 10: Association between attitude towards media and identity crisis among Pakistani youth

\begin{tabular}{|c|c|c|c|c|}
\hline \multirow{2}{*}{ Attitude towards media } & \multicolumn{3}{|c|}{ Identity crisis among Pakistani youth } & \multirow{2}{*}{ Total } \\
\cline { 2 - 5 } & Low & Medium & High & \\
\hline \multirow{2}{*}{ Low } & 12 & 11 & 1 & 24 \\
\cline { 2 - 5 } & $50.0 \%$ & $45.8 \%$ & $4.2 \%$ & $100.0 \%$ \\
\hline \multirow{2}{*}{ Medium } & 9 & 32 & 27 & 68 \\
\cline { 2 - 5 } & $13.2 \%$ & $47.1 \%$ & $39.7 \%$ & $100.0 \%$ \\
\hline \multirow{2}{*}{ High } & 2 & 18 & 38 & 58 \\
\cline { 2 - 5 } & $3.4 \%$ & $31.0 \%$ & $65.5 \%$ & $100.0 \%$ \\
\hline \multirow{2}{*}{ Total } & 23 & 61 & 66 & 150 \\
\cline { 2 - 5 } & $15.3 \%$ & $40.7 \%$ & $44.0 \%$ & $100.0 \%$ \\
\hline
\end{tabular}

Chi-square $=41.55 ;$ d.f. $=4 ;$ P-value $=.000^{\star *} ;$ Gamma $=.658 ;{ }^{* \star}=$ Highly significant

Table 10 presents the association between attitude towards media of the respondents and identity crisis among Pakistani youth. Chi-square value (41.55) shows a highly significant $(P=.000)$ association between attitude towards media of the respondents and identity crisis among Pakistani youth. Gamma value shows a positive relationship between the variables. It means youth attitude towards media positively associated with the identity crisis among Paksitan youth. So the hypothesis "Media of foreign countries strongly cause the identity crises among Pakistani youth" is accepted.

\section{Conclusion}

In this research, I investigated whether International media has influence on Pakistani youth or not. Analysis and interpretation of data have empirically demonstrated that International media has strongly influence youngsters in negative direction. It is found that these channels has vital role in replacing Pakistani culture with other cultures and changing life style, language and other aspects of Pakistani people. The results of the study showed that youngsters frequently watched international channels and frequent exposure to these channels plays a significant role in shaping their life style and identity.

Moreover, the teenagers admitted that the programs shown television portray the modern lifestyle, although some of them declined that it was the ideal lifestyle which they will like to adopt, especially the lifestyle of celebrities shown in these programs and they learnt some social values from TV such as fashion, communication, life style etc.

\section{References}

Afzal, A. (2010). Negative effects of foreign media. Available at this website: http://www.pakspectator.com/negitive-effects-of-foreignmedia.[Accessed October 2010].

Baran, J. (2009).Introduction to mass communication: media literacy and culture. New York: McGraw Hill.

Batool, U. (2007). What are impacts of Indian dressing in Pakistan? Society and politics. Available at this source: http://www.blurtit.com/q459730.html. [Accessed October 2010].

CIL. (2007).Center for intercultural learning Canada.

Dash ,N. (2004). Social and cultural anthropology,New Delhi: Atlantic Publication

Lane, J. \& S, Erison.(2007). Culture and politics.2nd Edition. England: Ashgate publishing limited. pp (16-17).

Mehmood, H. (2007). Basant becoming Pakistan's cultural festival. Available at this website: http://www.suite101.com/article.cfm /pakistans_culture_retired/37469/2. [Accessed November 2010].

Miles, S. (2000). Youth life styles in a changing world. Buckingham: Open University Press.

Murtaza, G. (2007). The impact of culture conflict on identity with an emphasis on Pakistan

Muncie, J. (2004). Youth and crime (2nd ed.). London: Sage Publications Inc.

Nisar, A. (2002). Cable operators should promote our social values and culture. The News, September 16, 2002.

Okoro, George. (2008). The effects of movies with sex content on teenage sexual attitudes and values.

Vivian, J. (2009). The media of mass communication (9th ed.). Boston, MA: Allyn and Bacon. 